\title{
Coordination of leaf hydraulic, anatomical, and economical traits in tomato seedlings acclimation to long-term drought
}

Shuang $\mathrm{Li}^{1,2}$, Abdoul Kader Mounkaila Hamani ${ }^{1,2}$, Yingying Zhang ${ }^{1}$, Yueping Liang ${ }^{1}$, Yang Gao ${ }^{1 *}$ and Aiwang Duan ${ }^{1 *}$

\begin{abstract}
Background: Leaf hydraulic and economics traits are critical for balancing plant water and $\mathrm{CO}_{2}$ exchange, and their relationship has been widely studied. Leaf anatomical traits determine the efficiency of $\mathrm{CO}_{2}$ diffusion within mesophyll structure. However, it remains unclear whether leaf anatomical traits are associated with leaf hydraulic and economics traits acclimation to long-term drought.
\end{abstract}

Results: To address this knowledge gap, eight hydraulic traits, including stomatal and venation structures, four economics traits, including leaf dry mass per area (LMA) and the ratio between palisade and spongy mesophyll thickness (PT/ST), and four anatomical traits related to $\mathrm{CO}_{2}$ diffusion were measured in tomato seedlings under the long-term drought conditions. Redundancy analysis indicated that the long-term drought decreased stomatal conductance $\left(\mathrm{g}_{\mathrm{s}}\right)$ mainly due to a synchronized reduction in hydraulic structure such as leaf hydraulic conductance $\left(K_{\text {leaf }}\right)$ and major vein width. Simultaneously, stomatal aperture on the adaxial surface and minor vein density $\left(V D_{\text {minor }}\right)$ also contributed a lot to this reduction. The decreases in mesophyll thickness ( $\left.T_{\text {mes }}\right)$ and chlorophyll surface area exposed to leaf intercellular air spaces $\left(S_{c} / S\right)$ were primarily responsible for the decline of mesophyll conductance $\left(g_{m}\right)$ thereby affecting photosynthesis. Drought increased leaf density (LD) thus limited $\mathrm{CO}_{2}$ diffusion. In addition, $\mathrm{LMA}$ may not be important in regulating $\mathrm{g}_{\mathrm{m}}$ in tomato under drought. Principal component analysis revealed that main anatomical traits such as $T_{\text {mes }}$ and $S_{C} / S$ were positively correlated to $K_{\text {leaf }}, V_{\text {minor }}$ and leaf thickness (LT), while negatively associated with PT/ST. Conclusions: These findings indicated that leaf anatomy plays an important role in maintaining the balance between water supply and $\mathrm{CO}_{2}$ diffusion responses to drought. There was a strong coordination between leaf hydraulic, anatomical, and economical traits in tomato seedlings acclimation to long-term drought.

Keywords: Hydraulic traits, Anatomical traits, Economics traits, Stomatal conductance, Mesophyll conductance, Drought

\footnotetext{
*Correspondence: gaoyang@caas.cn; duanaiwang@caas.cn

${ }^{1}$ Farmland Irrigation Research Institute, Key Laboratory of Crop Water Use and Regulation, Chinese Academy of Agriculture Sciences, Ministry of Agriculture and Rural Affairs, Xinxiang, Henan 453002, China Full list of author information is available at the end of the article
}

\begin{abstract}
Background
Drought, especially the prolonged and intense one, is one of the leading environmental factors limiting crop productivity and yield worldwide. Drought could seriously restrict agricultural and economic development $[1$, 2]. Leaves are directly involved in carbon assimilation, respiration, and water relations [3, 4]. Understanding the mechanisms of leaf functional traits can considerably advance our knowledge regarding plant adaptive
\end{abstract}

(C) The Author(s) 2021. Open Access This article is licensed under a Creative Commons Attribution 4.0 International License, which permits use, sharing, adaptation, distribution and reproduction in any medium or format, as long as you give appropriate credit to the original author(s) and the source, provide a link to the Creative Commons licence, and indicate if changes were made. The images or other third party material in this article are included in the article's Creative Commons licence, unless indicated otherwise in a credit line to the material. If material is not included in the article's Creative Commons licence and your intended use is not permitted by statutory regulation or exceeds the permitted use, you will need to obtain permission directly from the copyright holder. To view a copy of this licence, visit http://creativecommons.org/licenses/by/4.0/. The Creative Commons Public Domain Dedication waiver (http://creativeco mmons.org/publicdomain/zero/1.0/) applies to the data made available in this article, unless otherwise stated in a credit line to the data. 
survival strategies to suit the surrounding conditions. Leaf morphological and physiological plasticity is essential for plants to efficiently utilize finite environmental resources (e.g., soil water, nutrients, and light) when suffering from abiotic stresses [5]. Despite the varieties of leaf traits, those related to water and $\mathrm{CO}_{2}$ exchange have gained most of the attention recently [6,7]. One set of traits form a group of leaf hydraulic traits, such as stomatal traits and venation traits, which indicate how plants balance water demands and supplies under environmental stresses $[3,8,9]$. Another set of leaf traits is strongly associated with the balance between the investments and returns for water or nutrient resources and carbon, such as leaf maximum photosynthetic capacity $\left(\mathrm{A}_{\max }\right)$, leaf dry mass per area (LMA) and leaf nitrogen concentration, which are known as the leaf economic characteristics forming the so-called worldwide leaf economic spectrum $[4,10]$. Leaf hydraulic and economics traits play a crucial role in influencing material and energy exchange for plant adaptation to climate changes.

Water transport and $\mathrm{CO}_{2}$ uptake are two critical physiological processes involving in leaf function and thus influence photosynthetic capacity $[11,12]$. Stomata are "gatekeepers" on the epidermis of leaves that responsible for the exchange of gases (e.g., water vapor and $\mathrm{CO}_{2}$ ) between plant tissues and the atmosphere $[13,14]$. Thus, stomata plays significant roles in the regulation of water and carbon cycling $[14,15]$. Among stomatal conductance $\left(g_{s}\right)$, the stomatal morphology such as stomatal density (SD), stomatal size (SS) and stomatal aperture (SA) contributed to a lot in regulating stomatal behavior response to changing environmental conditions, particularly long-term drought. The long-term drought generally results in smaller stomata and higher density across species $[16,17]$, which may allow plants to make faster and more rapid responses to minimize the water loss and enhance fine regulation of plant water use. This balance is generally achieved by regulating leaf vein density, which has a critical role in water supply and evaporative demand $[3,8,9]$. Analysis of global variations in leaf functional traits-the leaf economics spectrumhas established that the variation in LMA is strongly associated with plant photosynthetic capacity. It has been documented that LMA would increase, decrease or do not change in response to drought, which exhibits high plasticity between species due to drought alters the pattern of combination between bulk leaf thickness (LT) and leaf density (LD) at the primary level $[18,19]$. Though a decoupled relationship between leaf economics and hydraulic traits in rain forest trees was reported by several researchers [20,21], evidences are now mounting that these two suites are coupled across woody and herbaceous species in response to different water conditions and other environmental factors from fine to global scales $[6,10,22,23]$. However, the analysis of water and $\mathrm{CO}_{2}$ diffusion at the leaf morphological structure level might be too coarse, since those move out or into mesophyll tissues should pass through a series of ultrastructural characteristics, which can directly reflect mechanistic responses related to gas exchange efficiency.

These ultrastructural characteristics form mesophyll anatomical traits, which are often found to be related to the mesophyll conductance to $\mathrm{CO}_{2}\left(\mathrm{~g}_{\mathrm{m}}\right)$ from the intercellular airspace $\left(\mathrm{C}_{\mathrm{i}}\right)$ to chloroplasts, such as mesophyll thickness $\left(\mathrm{T}_{\text {mes }}\right)$, cell wall thickness $\left(\mathrm{T}_{\mathrm{cw}}\right)$, the volume fraction of intercellular air spaces $\left(f_{\text {ias }}\right)$ and chlorophyll surface area exposed to leaf intercellular air spaces per leaf area $\left(\mathrm{S}_{\mathrm{c}} / \mathrm{S}\right)$ [24-26]. Previous researches suggested that LMA limits photosynthetic efficiency by affecting $\mathrm{g}_{\mathrm{m}}$ [27-29]. Some reviews and reports also reported that the $g_{m}$ is largely determined by mesophyll anatomic traits in adaptation to long term stresses such as drought [24, 30], potassium deficiency [31] and high leaf-to-air vapor pressure difference (VPD) [32]. On the other hand, leaf hydraulic conductance $\left(\mathrm{K}_{\text {leaf }}\right)$, representing the efficiency of water transport through the petiole to leaf vein system, can mediate the covariation of $g_{s}$ and $g_{m}$ responses to environmental factors through the shared diffusion pathways of water and $\mathrm{CO}_{2}$ within mesophyll [11, 33]. Therefore, revealing the correlation between anatomical and hydraulic traits as well as economics traits seemed to be more beneficial for us in understanding the physiological mechanisms of leaf functions acclimation to water limitation. However, it remains unclear whether variations in leaf anatomical traits are associated with leaf hydraulic and economics traits acclimation to longterm drought especially within a cultivated crop species. A detailed investigation is required to fill essential gaps in plant selection and breeding for desired agronomic leaf functional traits.

Tomato (Solanum lycopersicum) is one of the most widely cultivated vegetable plants globally and a model crop in agronomic research. Numerous studies have proven that drought affects tomato yield and fruit quality $[34,35]$. Understanding the significance of leaf hydraulic, anatomical, and economical traits to the process of trading water and $\mathrm{CO}_{2}$ in tomato would be with a great theoretical and practical meaning. To this end, eight key leaf hydraulic traits, four common economics traits and four anatomic traits which related to $\mathrm{CO}_{2}$ diffusion efficiency and photosynthesis were studied in this research (Table 1). All these traits are measured or collected on the last day at the end of the experiment. The main objectives of this study were to (1) investigate how leaf 
Table 1 The measured leaf functional traits and their categorization

\begin{tabular}{|c|c|c|c|}
\hline Group & Traits & Abbr. & Unit \\
\hline \multirow[t]{8}{*}{ Leaf hydraulic traits } & Leaf hydraulic conductance & $\mathrm{K}_{\text {leaf }}$ & $\mathrm{mmol} \mathrm{m}{ }^{-2} \mathrm{~s}^{-1} \mathrm{MPa}^{-1}$ \\
\hline & Minor venation density & $V D_{\text {minor }}$ & $\mathrm{mm} \mathrm{mm^{-2 }}$ \\
\hline & Major venation density & $V D_{\text {major }}$ & $\mathrm{mm} \mathrm{mm^{-2 }}$ \\
\hline & Major vein width & & $\mu \mathrm{m}$ \\
\hline & Stomatal density & SD & $\mathrm{mm}^{-2}$ \\
\hline & Stomatal size & SS & $\mu m^{2}$ \\
\hline & Stomatal aperture & SA & $\mu \mathrm{m}$ \\
\hline & Maximum stomatal conductance to water vapor & $g_{w \max }$ & $\mathrm{mol} \mathrm{H} \mathrm{O} \mathrm{m}^{-2} \mathrm{~s}^{-1}$ \\
\hline \multirow[t]{4}{*}{ Leaf economics traits } & Leaf dry mass per area & LMA & $\mathrm{g} \mathrm{m}^{-2}$ \\
\hline & Leaf thickness & LT & $\mathrm{mm}$ \\
\hline & Leaf density & LD & $\mathrm{g} \mathrm{cm}^{-3}$ \\
\hline & Ratio between palisade and spongy mesophyll thickness & $\mathrm{PT} / \mathrm{ST}$ & $\mu \mathrm{m} \mu \mathrm{m}^{-1}$ \\
\hline \multirow[t]{4}{*}{ Leaf anatomic traits } & Mesophyll thickness & $T_{\text {mes }}$ & $\mu \mathrm{m}$ \\
\hline & Cell wall thickness & $T_{c w}$ & $\mu \mathrm{m}$ \\
\hline & Volume fraction of intercellular air spaces & $f_{\text {ias }}$ & $\%$ \\
\hline & $\begin{array}{l}\text { Chlorophyll surface area exposed to leaf intercellular air spaces per } \\
\text { leaf area }\end{array}$ & $\mathrm{S}_{\mathrm{C}} / \mathrm{S}$ & $m^{2} m^{-2}$ \\
\hline
\end{tabular}

hydraulic, economics and anatomical traits respond to intense long-term drought, and to (2) test whether these three leaf traits are coordinated acclimation to drought in the specific cultivated tomato plants.

\section{Results}

\section{Variations in leaf gas exchange and functional traits to drought}

The leaf gas exchange parameters of tomato seedlings were markedly sensitive to drought (Fig. 1). Figure 1a and $b$ illustrated that drought significantly decreased $g_{s}$ and $g_{m}$ by $86.70 \%$ and $92.04 \%$, respectively. A positive and significant correlation was found between $\mathrm{CO}_{2}$ diffusions, $T_{r}$ and $A_{n}$ (Table S1). Consequently, $T_{r}$ and $A_{n}$ were significantly lower under drought than the wellwatered treatment (Fig. 1c and d).

Drought reduced the stomatal aperture and size on both the adaxial and abaxial surface of leaves, but no difference of these two traits was observed between the adaxial and abaxial surface in response to drought (Table 2; Fig. S2a-d). The distribution frequency of stomatal aperture fitted a gaussian function (Fig. 2). According to the fitting curve results, the order of stomatal opening size with the highest occurrence frequency was: stomatal aperture on the adaxial surface in $\mathrm{CK}\left(\mathrm{CK}_{\mathrm{ada}}\right)>$ stomatal aperture on the abaxial surface in $C K\left(\mathrm{CK}_{\mathrm{aba}}\right)>$ stomatal aperture on the adaxial surface in drought $\left(\right.$ Drought $_{\text {ada }}$ ) > stomatal aperture on the abaxial surface in drought (Drought $\left.\mathrm{aba}_{\mathrm{a}}\right)$. From the column results, the relative frequency of 5-5.5 $\mu \mathrm{m}$ aperture in $\mathrm{CK}_{\mathrm{ada}}$ contributed to $53.33 \%$. Drought did not affect SD on the abaxial surface, whereas markedly increased SD on the adaxial surface. In contrast, $\mathrm{g}_{\mathrm{wmax}}$ on the abaxial surface was lower in drought plants compared with $\mathrm{CK}$. Major vein width, $\mathrm{VD}_{\text {minor }}$ and $\mathrm{K}_{\text {leaf }}$ were significantly reduced under drought, whereas $\mathrm{VD}_{\text {major }}$ was unaffected by drought (Table 3 ). The associations between water loss and stomatal morphology as well as water supply indexes from RDA were presented in Fig. 3. Four key factors affecting the $g_{s}$ and $\mathrm{T}_{\mathrm{r}}$ were $\mathrm{K}_{\text {leaf }}(P=0.016)$, major vein width $(P=0.004)$, SA on the adaxial surface $(P=0.038)$ and $\operatorname{VD}_{\text {minor }}(P=$ $0.016)$, which explained $94.82 \%$ of the total variance.

Among the economics traits, the leaf thickness (LT) decreased, while the leaf density (LD) increased in response to drought, whereas LMA was unaffected by drought (Table 4). The ratio between palisade and spongy mesophyll thickness (PT/ST) was higher under drought than CK. Compared to CK, drought significantly decreased $\mathrm{T}_{\text {mes }}$ (Figs. $4 \mathrm{a}$ and $\mathrm{b}$ and $5 \mathrm{a}$ ) and chlorophyll surface area exposed to leaf intercellular air spaces per leaf area $\left(\mathrm{S}_{\mathrm{c}} / \mathrm{S}\right)$ (Figs. $4 \mathrm{c}$ and $\mathrm{d}$ and $5 \mathrm{~d}$ ), whereas drought increased $\mathrm{T}_{\mathrm{cw}}$ (Fig. 5b). There was no significant difference in $\mathrm{f}_{\text {ias }}$ between in CK and drought treatment (Fig. 5c). The RDA revealed the associations among leaf anatomic, economics traits and carbon fixation (Fig. 6), which accounted for $98.79 \%$ of the variability. $T_{\text {mes }}$ and $S_{c} / S$ were strongly related to the increase of $g_{m}$ and $A_{n}$. However, PT/ST and LD were negatively correlated with $g_{m}$ and $A_{n}$ 

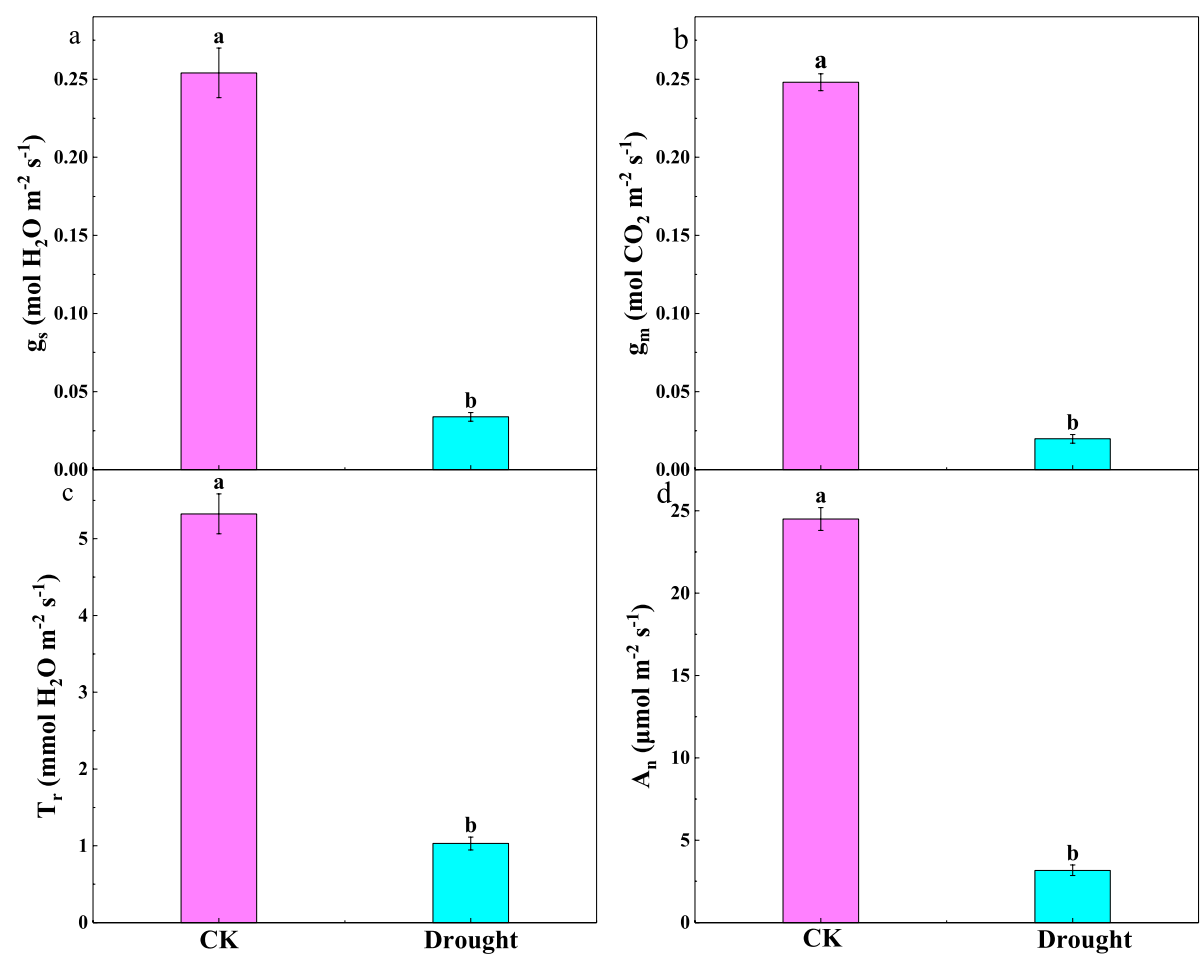

Fig. 1 (a) Stomatal conductance $\left(g_{s}\right)$, (b) mesophyll conductance $\left(g_{m}\right),(\mathbf{c})$ transpiration rate $\left(T_{r}\right)$ and $(\mathbf{d})$ net assimilation rate $\left(A_{n}\right)$ for tomato under the well-watered (CK) and drought treatments. Data are means \pm standard error (SE) $(n=6)$. Different letters denote statistically significant differences between treatments $(P<0.01)$

Table 2 Stomatal aperture, stomatal size, stomatal density (SD) and maximum stomatal conductance to water vapor ( $g_{\text {wmax }}$ ) on the adaxial and abaxial surfaces of leaves for tomato under the well-watered (CK) and drought conditions

\begin{tabular}{|c|c|c|c|c|}
\hline Treatment & stomatal aperture $(\mu \mathrm{m})$ & stomatal size $\left(\mu \mathrm{m}^{2}\right)$ & $\begin{array}{l}\text { SD } \\
\left(\mathrm{mm}^{-2}\right)\end{array}$ & $\begin{array}{l}g_{\mathrm{wmax}} \\
\left(\mathrm{mol} \mathrm{H}_{2} \mathrm{O} \mathrm{m}^{-2} \mathrm{~s}^{-1}\right)\end{array}$ \\
\hline $\mathrm{CK}_{\mathrm{ada}}$ & $4.57 \pm 0.3 b$ & $50.91 \pm 6.85 b$ & $204.18 \pm 9.8 c$ & $0.65 \pm 0.06 b$ \\
\hline $\mathrm{CK}_{\mathrm{aba}}$ & $5.30 \pm 0.1 \mathrm{a}$ & $63.39 \pm 3.4 \mathrm{a}$ & $291.68 \pm 1.7 \mathrm{a}$ & $0.98 \pm 0.03 \mathrm{a}$ \\
\hline Drought $_{\text {ada }}$ & $3.73 \pm 0.2 c$ & $38.98 \pm 1.6 b c$ & $226.56 \pm 5.4 b$ & $0.67 \pm 0.03 b$ \\
\hline Drought $_{\mathrm{aba}}$ & $3.34 \pm 0.1 \mathrm{c}$ & $32.28 \pm 3.1 c$ & $295.08 \pm 9.6 \mathrm{a}$ & $0.80 \pm 0.06 b$ \\
\hline
\end{tabular}

\section{Coordination among leaf hydraulic, anatomical, and economical traits acclimation to drought}

To better understand the relationships among leaf hydraulic, anatomical, and economical traits, the principal component analyses (PCA) were performed across three main tomato cultivars in China (Fig. 7). LD, LT, LMA and $\mathrm{g}_{\mathrm{wmax}}$ loaded in the positive end, while $\mathrm{T}_{\mathrm{cw}}$ and $\mathrm{f}_{\text {ias }}$ loaded in the negative end at the first component axis, which accounting for $68.18 \%$ of the total variation. The positive side on the second axis was mostly defined by PT/ST, while the negative side was defined by the $\mathrm{K}_{\text {leaf }}, \mathrm{S}_{\mathrm{c}} / \mathrm{S}$ and $\mathrm{T}_{\text {mes }}$. Together, the first two major axes explained about $97.84 \%$ of the total variation observed in the three tomato cultivars. The results indicated that there was a trade-off among leaf hydraulic traits, economics traits and anatomical traits acclimation to drought across the three main tomato cultivars.

\section{Discussion}

Although drought pretreatment has a priming effect on plant physiological activity [36], our results indicated that $A_{n}$ of tomato seedling under drought was still significantly lower than that under the well-watered conditions (Fig. 1d). Previous studies have suggested that the decline of $\mathrm{A}_{\mathrm{n}}$ was mainly related to low $\mathrm{CO}_{2}$ diffusion 


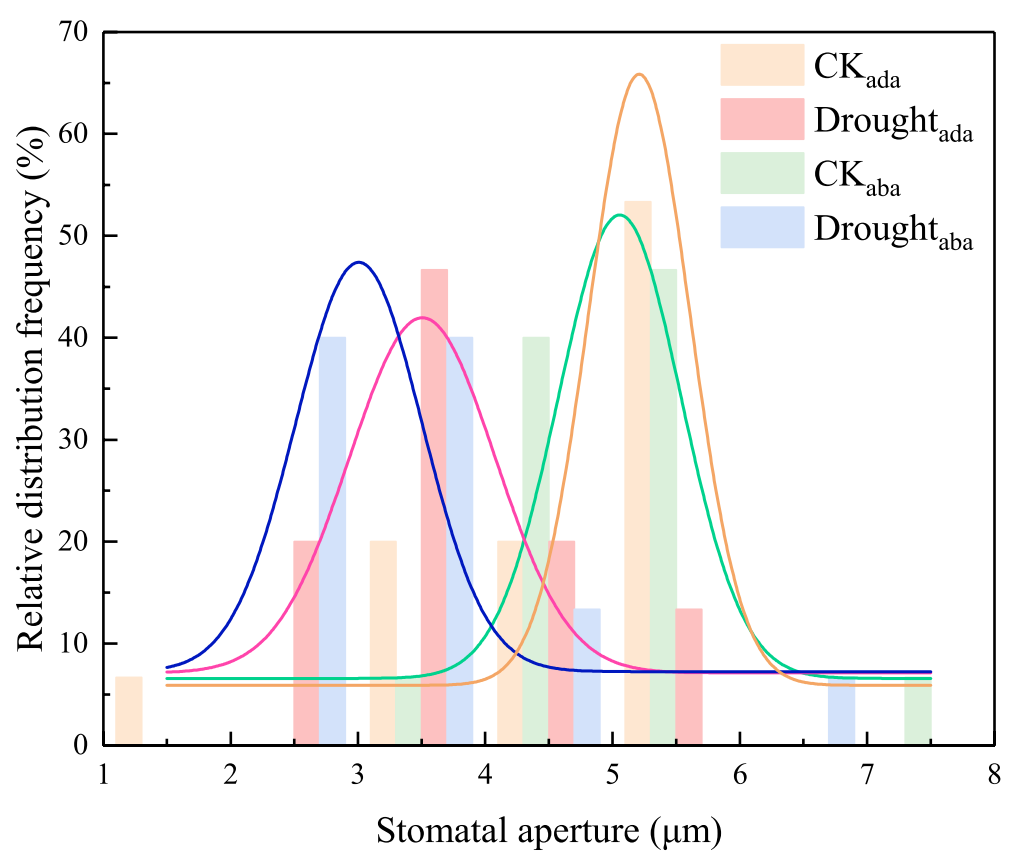

Fig. 2 The relative distribution frequency of stomatal aperture on the adaxial and abaxial surface in the well-watered (CK) and drought tomato plants

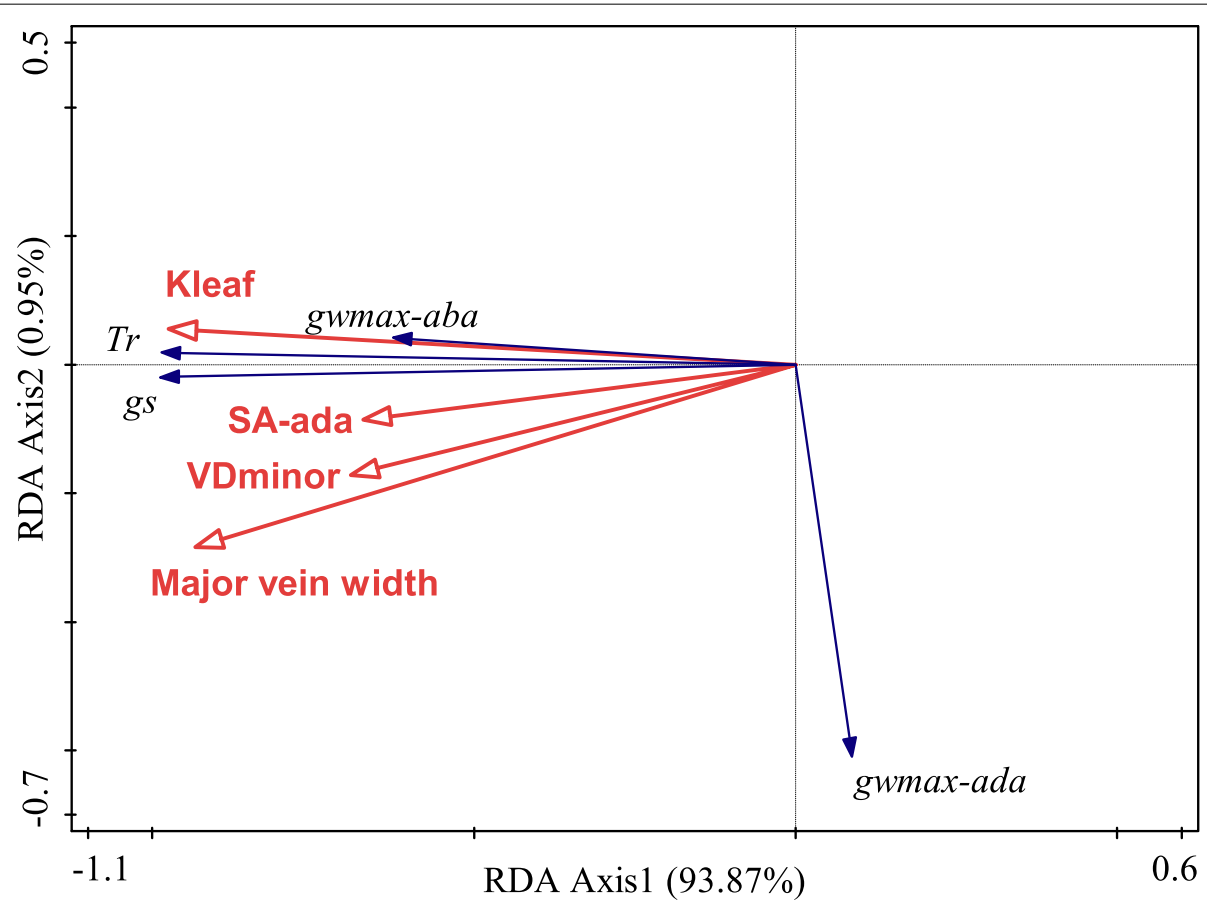

Fig. 3 Redundancy analysis (RDA) presenting the association among traits related to water loss, stomatal structural and water supply

conductance $[11,28,32]$. Besides $g_{s}, g_{m}$ is also an important factor regulating plant photosynthetic responses to environmental stress, since $g_{m}$ determines the drawdown of $\mathrm{CO}_{2}$ from sub-stomatal cavities to chloroplasts [26, 37]. Thus, the reduction in $A_{n}$ was mainly explained by the synchronized decrease in $g_{s}$ and $g_{m}$, which was 
Table 3 Major vein width, major vein density $\left(V D_{\text {major }}\right)$, minor vein density $\left(V D_{\text {minor }}\right)$ and leaf hydraulic conductance $\left(K_{\text {leaf }}\right)$ for tomato under the well-watered and drought conditions

\begin{tabular}{|c|c|c|c|c|}
\hline Treatment & $\begin{array}{l}\text { Major vein } \\
\text { width }(\mu \mathrm{m})\end{array}$ & $\begin{array}{l}V_{\text {major }} \\
\left(\mathrm{mm} \mathrm{mm}^{-2}\right)\end{array}$ & $\begin{array}{l}V_{\text {minor }} \\
\left(\mathrm{mm} \mathrm{mm}^{-2}\right)\end{array}$ & $\begin{array}{l}\mathrm{K}_{\text {leaf }} \\
(\mathrm{mmol} \\
\left.\mathrm{m}^{-2} \mathrm{~s}^{-1} \mathrm{MPa}^{-1}\right)\end{array}$ \\
\hline CK & $289.43 \pm 3.9 a$ & $0.043 \pm 0.01 \mathrm{a}$ & $6.16 \pm 0.1 \mathrm{a}$ & $5.03 \pm 0.2 \mathrm{a}$ \\
\hline Drought & $252.29 \pm 1.2 b$ & $0.045 \pm 0.003 a$ & $5.59 \pm 0.04 b$ & $0.73 \pm 0.1 b$ \\
\hline
\end{tabular}

Table 4 Leaf dry mass per area (LMA), leaf thickness (LT), leaf density (LD) and the ratio between palisade and spongy mesophyll thickness (PT/ST) for tomato seedlings under the wellwatered (CK) and drought conditions

\begin{tabular}{lllll}
\hline Treatment & LMA $\left(\mathbf{g ~ m}^{-\mathbf{2}}\right)$ & $\mathbf{L T}(\mathbf{m m})$ & $\mathbf{L D}\left(\mathbf{g ~ c m}^{-\mathbf{3}}\right)$ & $\begin{array}{l}\text { PT/ST }(\boldsymbol{\mu m} \\
\boldsymbol{\mu m}\end{array}$ \\
\hline CK & $54.37 \pm 2.1 \mathrm{a}$ & $0.30 \pm 0.01 \mathrm{a}$ & $0.18 \pm 0.01 \mathrm{~b}$ & $0.65 \pm 0.02 \mathrm{~b}$ \\
Drought & $50.09 \pm 1.5 \mathrm{a}$ & $0.25 \pm 0.01 \mathrm{~b}$ & $0.21 \pm 0.01 \mathrm{a}$ & $0.92 \pm 0.07 \mathrm{a}$ \\
\hline
\end{tabular}
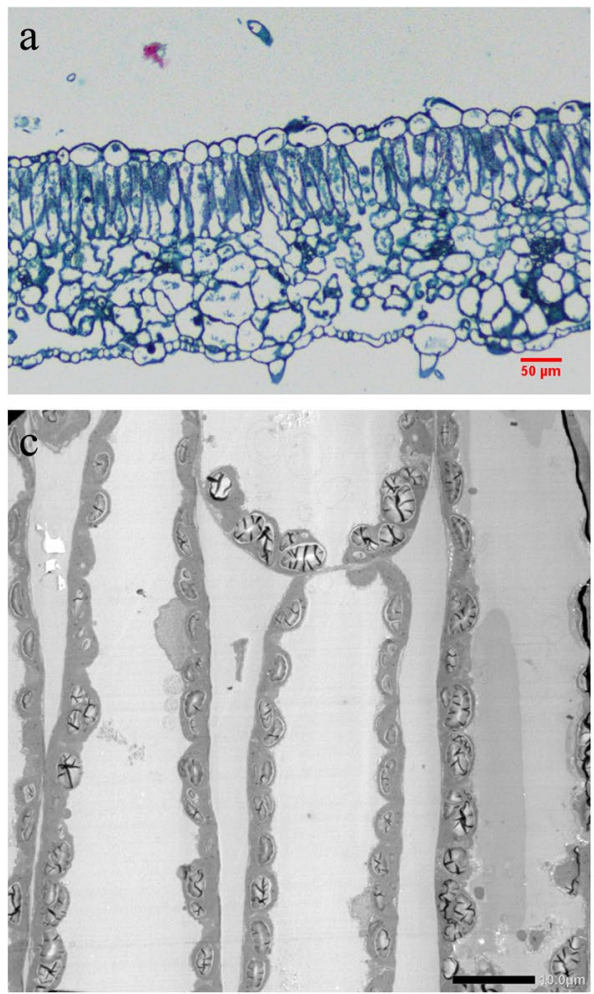

CK confirmed by the observed decline in chloroplast $\mathrm{CO}_{2}$ concentration $\left(\mathrm{C}_{\mathrm{c}}\right)$ (Fig. S1). However, drought unaffected intercellular $\mathrm{CO}_{2}$ concentration $\left(\mathrm{C}_{\mathrm{i}}\right)$. Although observation of a significant decrease in $A_{n}$ by drought is not new $[30,38]$, the mechanisms behind the reduction of $g_{s}$ and $\mathrm{g}_{\mathrm{m}}$ related to anatomic traits induced by drought were systematically and extensively considered in this study.

\section{Importance of leaf hydraulic traits in determining water loss to long-term drought}

Under low water availability, a fundamental challenge for plants will be to balance the transpiration demand and water supply. Stomatal closure acts as an early response to minimize the transpiration water-loss under drought $[8,39]$. On the one hand, an efficient water supply within leaves is crucial to maintain stomata opening [7, 8]. According to the RDA model, $\mathrm{K}_{\text {leaf }}$ was the most important factor affecting $g_{s}$ and $T_{r}$ (Fig. 3). In this case, $g_{s}$ decreased concomitantly accompanied by a reduction in $\mathrm{K}_{\text {leaf }}$ under drought, in agreement with previous studies $[33,38,40] . K_{\text {leaf }}$ is composed of two main components, the conductance within the xylem $\left(\mathrm{K}_{\mathrm{x}}\right)$ and the conductance through mesophyll tissues outsides the xylem $\left(\mathrm{K}_{\mathrm{ox}}\right)$; therefore, an operative xylem conduit is important in facilitating water transport within the xylem [12, 41, 42].
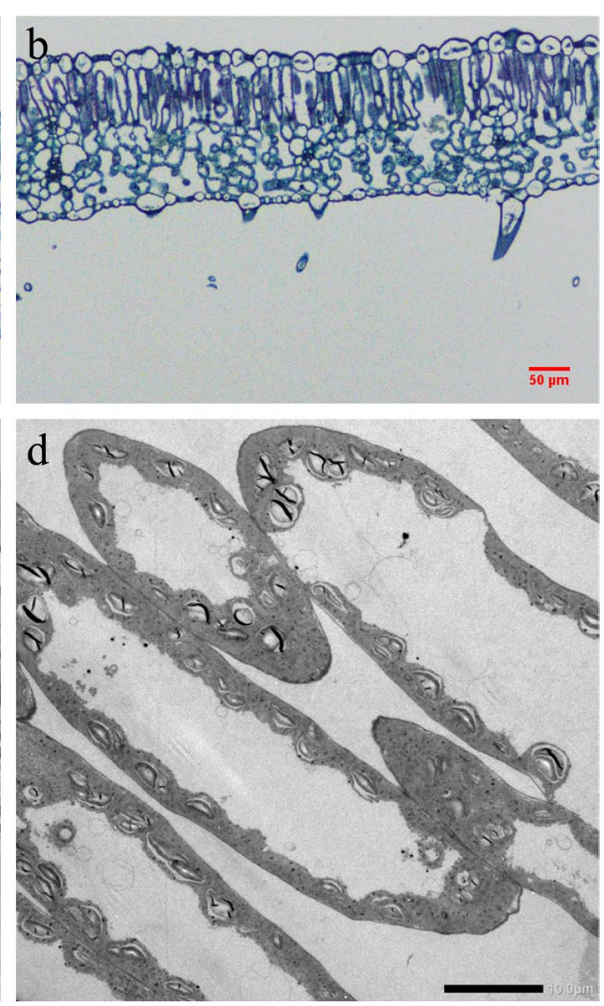

\section{Drought}

Fig. 4 Paraffin vertical sections for leaf (a-b) and ultrathin section for mesophyll cell structure (c-d) for tomato seedlings under well-watered (CK) and drought treatments. Scale bars: 1.07 pixels / $\mu \mathrm{m}$ for a-b; 29.7 pixels / $\mu \mathrm{m}$ for c; 35.64 pixels / $\mu \mathrm{m}$ for $d$ 

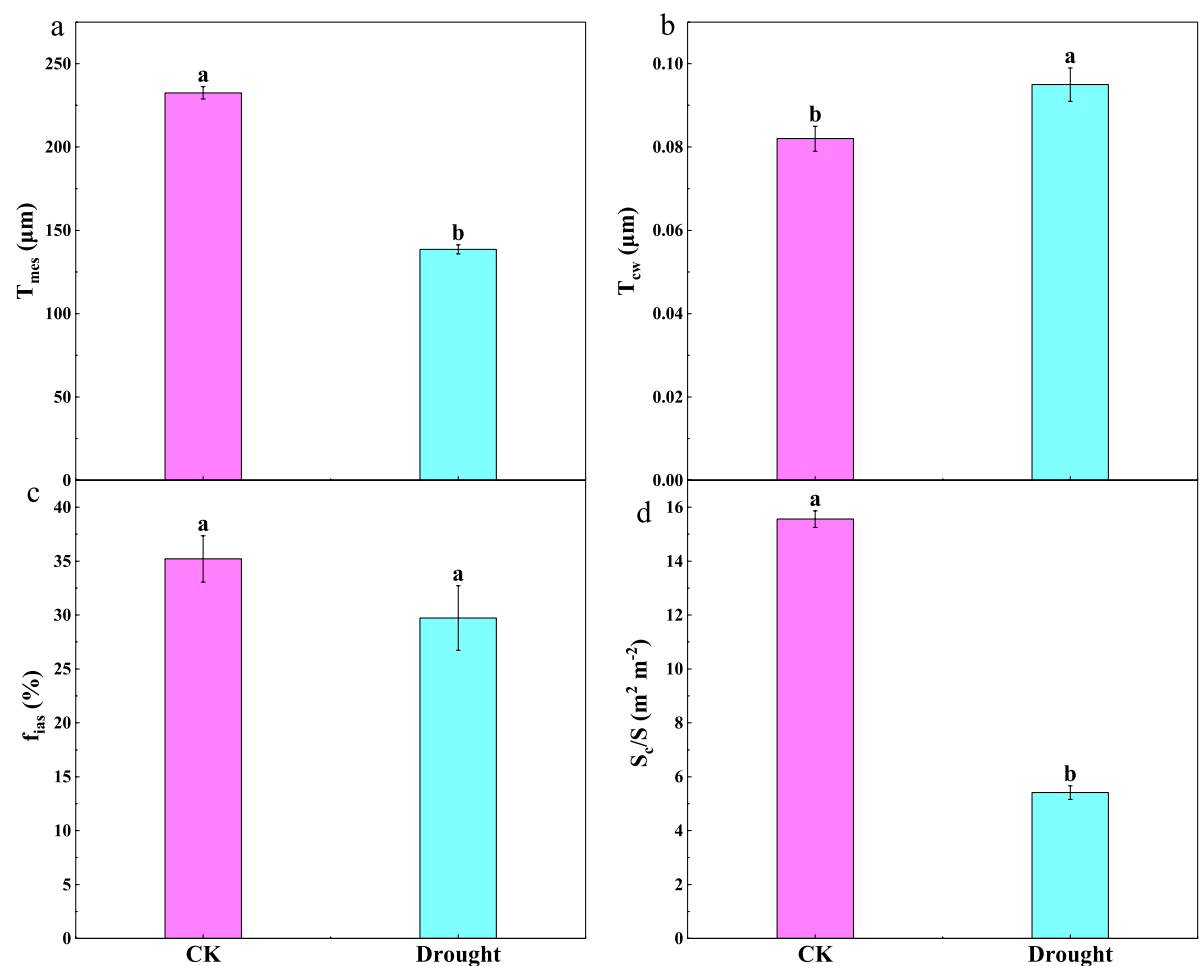

Fig. 5 Changes in (a) the mesophyll thickness $\left(T_{\text {mes }}\right),(\mathbf{b})$ cell wall thickness $\left(T_{c w}\right),(\mathbf{c})$ volume fraction of intercellular air spaces $\left(f_{i a s}\right)$ and $(\mathbf{d})$ chlorophyll surface area exposed to leaf intercellular air spaces per leaf area $\left(S_{C} / S\right)$ in tomato seedlings under the well-watered $(C K)$ and drought treatments. Data are means \pm standard error $(S E)(n=6)$. Different letters denote statistically significant differences between treatments $(P<0.01)$

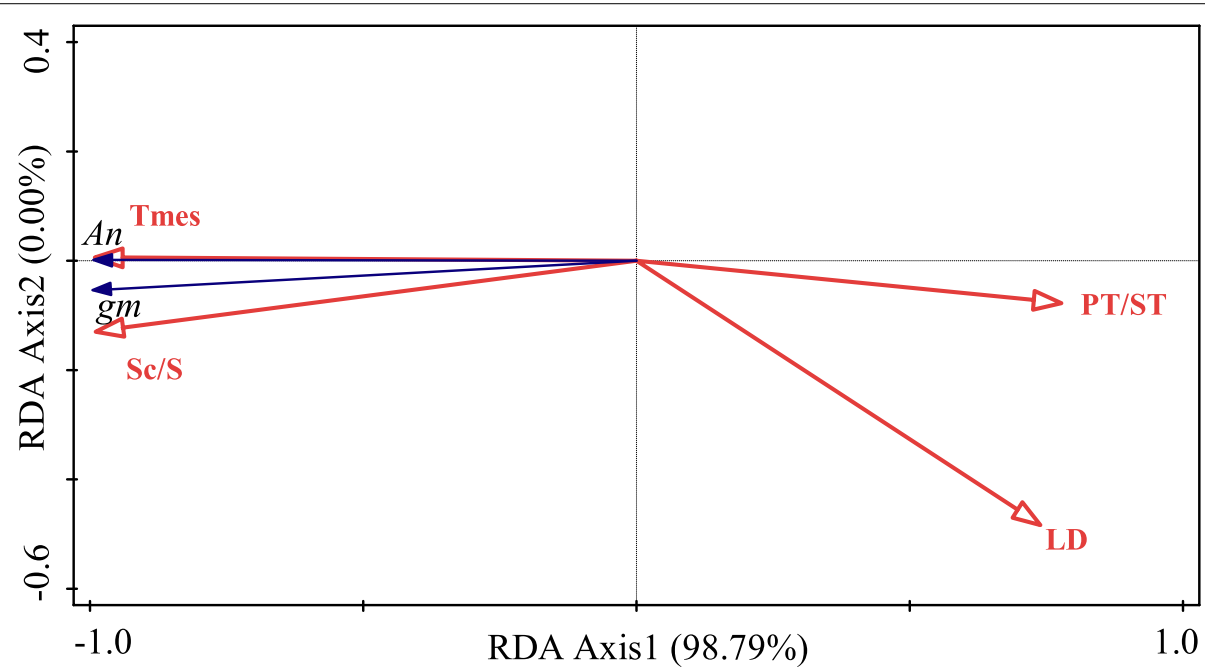

Fig. 6 Redundancy analysis (RDA) presenting the association of carbon fixation with leaf economical traits and mesophyll anatomic traits. Trait abbreviations: PT/ST (ratio between palisade and spongy mesophyll thickness), $T_{\text {mes }}$ (mesophyll thickness), LD (leaf density), $S_{C} / S$ (chlorophyll surface area exposed to leaf intercellular air spaces)

However, during leaf dehydration, air bubbles may invade into vascular system and subsequent blockaded the xylem conduits owing to exceeding the hydraulic safety thresholds caused by the increases in xylem tension under drought $[43,44]$, which led to a decrease in $K_{x}$. Moreover, although the data of hormonal signals (mainly 


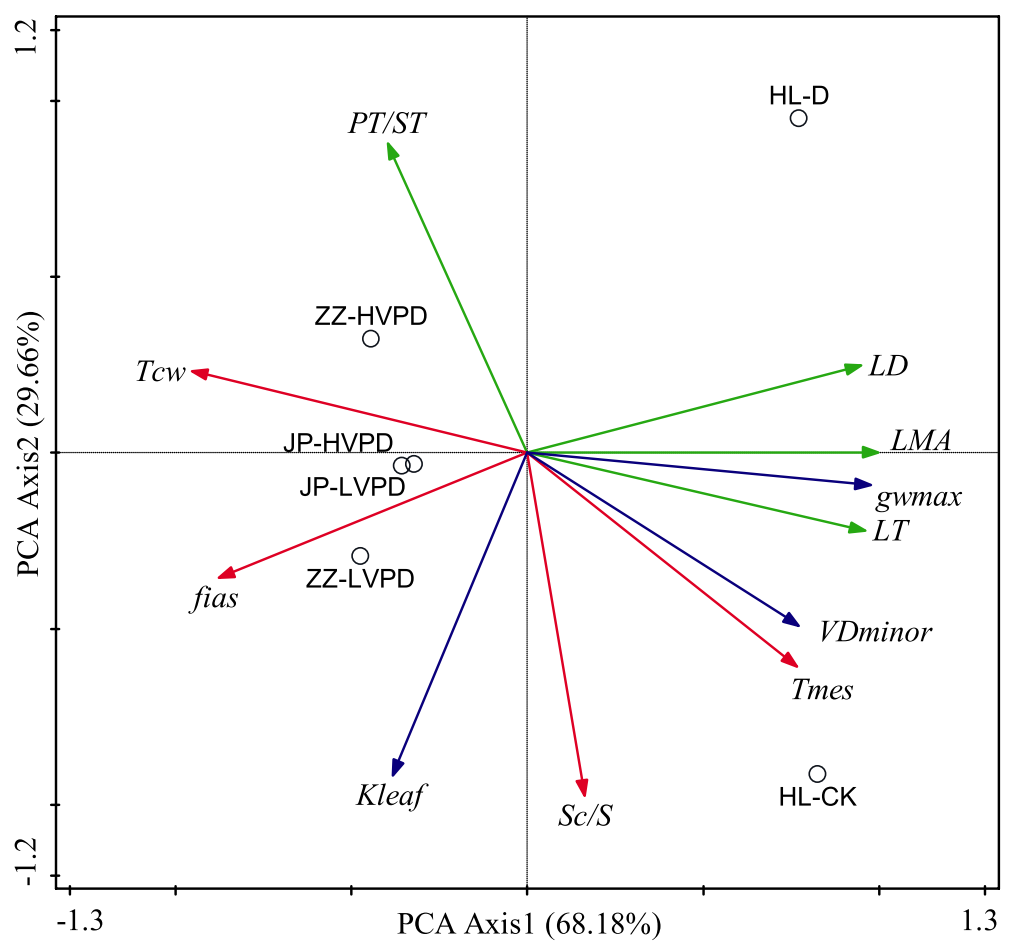

Fig. 7 Principal component analyses (PCA) on leaf hydraulic traits (blue lines), anatomical traits (red lines) and economical traits (green lines) by using original data. Values in bracket are percentages explained by the first two components. ZZ and JP refer to Zhongza and Jinpeng tomato cultivars, VPD refers to vapour pressure deficit, HVPD and LVPD refer to high VPD and low VPD. Data of ZZ and JP come from [32]. HL represents Helan tomato cultivars, CK and D mean well-watered and drought-stressed treatments in this study. Data are the means $(n=3-6)$

abscisic acid, $\mathrm{ABA}$ ) were not shown in the present, it has been proven recently that drought induced ABA accumulation in tomato plants could indirectly increase the risk of hydraulic failure and thus led to induced stomatal closure $[45,46]$.

On the other hand, leaf vein, as distinct water and nutrients transport systems, plays vital roles in determining the capacity of water transport $[3,6,47]$. In the present study, though $\mathrm{VD}_{\text {major }}$ was unchanged, the major vein width and $\mathrm{VD}_{\text {minor }}$ were significantly lower under drought than the well-watered plants, suggesting that drought impeded the vein development and distribution. A small vessel diameter and short vein distribution mean not only a reduction for water transport efficiency from xylem conduits within the bundles sheath cells but also an increased resistance for water movement from the xylem into mesophyll cells [26, 40, 48]. It is not surprising that the coordination among the major vein width, $\mathrm{VD}_{\text {minor }}$ and $\mathrm{K}_{\text {leaf }}$ was also noteworthy (Fig. S3 and Fig. 3). Besides the decline of $\mathrm{K}_{\mathrm{x}}$, lower $\mathrm{VD}_{\text {minor }}$ tends to decrease $\mathrm{K}_{\mathrm{ox}}$ due to its effect on hydraulic path length and bundle sheath cell (BS) surface area [49], which deserves more detailed investigation in future work. Hence, leaf xylem anatomy might play a more crucial role in maintaining $\mathrm{K}_{\text {leaf }}$ and therefore $\mathrm{g}_{\mathrm{s}}$ acclimation to severe drought.
Last but not least, stomatal morphology including stomatal number and size were suggested to be an adaptive mechanism in plants response to environmental factors such as temperature, water status, VPD, and $\mathrm{CO}_{2}$ concentration $[9,15,17,50]$. As previously reported, leaf stomatal aperture and size on both leaf sides decreased with drought in the present study (Table 2). The smaller stomata tend to open or close more rapidly than larger stomata in response to unpredictable water availability and thus optimize water loss and carbon assimilation [13, 14, 39]. Furthermore, drought increased SD on the adaxial surface that might due to the decrease of stomatal aperture[51]. However, drought did not reduce SD on the abaxial surface as well as $g_{w \max }$ on the adaxial surface. In fact, this higher flexibility of stomatal morphology and distribution may provide an advantage for plants maintenance of photosynthesis under such a severe drought by shortening the pathway for $\mathrm{CO}_{2}$ transport from lower leaf surface to the chloroplasts in spongy mesophyll cell [52]. Meanwhile, we also noticed that $\mathrm{VD}_{\text {minor }}$ and the major vein width were closely coordinated with stomatal aperture on both sides and negatively related to SD in our study (Fig. S3), which was also in accordance 
with many studies [32, 53]. It is possible that drought restricted the stomatal opening and increased stomatal number to match the balance between in water supply and carbon gain capacity. Consequently, lower water supply reduced $\mathrm{g}_{\mathrm{s}}$ and $\mathrm{T}_{\mathrm{r}}$ synchronously.

\section{Importance of leaf anatomical traits in determining carbon returns to long-term drought}

Many authors have reported that leaf anatomical properties play a substantial role in regulating $g_{m}[25,28,32$, 54]. The $\mathrm{CO}_{2}$ diffusion efficiency from the intercellular airspaces to chloroplasts is mainly determined by gas and liquid phase conductance. There is evidence that the former is mainly influenced by $\mathrm{f}_{\text {ias }}$ and $\mathrm{T}_{\text {mes }}$ [30]. In this study, drought did not affect $f_{\text {ias }}$, suggesting that $f_{\text {ias }}$ may not exert a significant effect on $g_{m}$. However, the drought-stressed tomato leaves had lower $\mathrm{T}_{\text {mes }}$ than the well-watered tomato and $\mathrm{T}_{\text {mes }}$ showed a strong positive correlation to $g_{m}$ (Figs. 5 and 6), mainly due to a thinner mesophyll may decrease the total surface area of $\mathrm{CO}_{2}$ assimilation under stress.

Concomitantly, it has been confirmed that liquid phase conductance was primarily responsible for the variation in $g_{m}$, especially for tomato cultivars $[25,31,32]$. In the present study, leaf anatomy of liquid phase such as $\mathrm{T}_{\mathrm{cw}}$ and $\mathrm{S}_{\mathrm{c}} / \mathrm{S}$ were affected by drought. In addition, the strong positive correlation between $\mathrm{S}_{\mathrm{c}} / \mathrm{S}$ and $\mathrm{g}_{\mathrm{m}}$ was observed in Fig. 6 and in other studies [55]. Variability in $S_{c} / S$ is closely correlated with the size, amount, and distribution of chloroplasts $[24,56]$. Perhaps drought reduced the size, amount, and distribution of chloroplasts, thus decreased the mesophyll surface area. Additionally, a thick cell wall is likely to lengthen $\mathrm{CO}_{2}$ diffusion through the plasma lemma [57]. Apart from $\mathrm{T}_{\text {mes }}, \mathrm{S}_{\mathrm{c}} / \mathrm{S}$ and $\mathrm{T}_{\mathrm{cw}}$, other leaf anatomical traits (such as distance from the chloroplasts to the cell wall or chloroplast thickness) and biochemical components in membrane were also affected by drought [24, 26]. Future studies should focus on the comprehensive effects of anatomical traits and biochemical components on drought acclimation.

LMA has been found to be negatively associated with $\mathrm{g}_{\mathrm{m}}$ in tomato species [29]. In contrast, there was no significant relationship between LMA and $g_{m}$ in this study. The inconsistent results may be due to drought induced an inverse variation between the two components of LMA, i.e., LT and LD. Despite this, the ratio between palisade and spongy mesophyll thickness (PT/ST) was negatively correlated to $g_{m}$ (Fig. 6). Similar trends of change in these variables were also reported by $\mathrm{Du}$ et al. [32] in tomato plants, indicating that there was a trade-off between palisade tissues and spongy tissues to acclimate to drought [6], possibly due to drought had a more substantial influence on spongy tissues than palisade tissues.

\section{Leaf anatomical traits were coordinate with hydraulic} and economics traits acclimation to drought

Yin et al. [6] reported that leaf economics and hydraulic traits were coupled on the Loess Plateau in China, where water availability is a key limiting factor. However, the role of anatomy related to photosynthetic capacity on this coordination is lacking. Thus, we studied the relationships between leaf hydraulic, economics and anatomical traits within three main tomato cultivars (data of another two cultivars from [32] in response to VPD, a measure of the atmospheric demand for water). Similar to soil moisture,VPD has direct influences on stomatal conductance and carbon uptake $[58,59]$. According to PCA, mesophyll anatomy (such as $\mathrm{T}_{\text {mes }}$ and $\mathrm{S}_{\mathrm{c}} / \mathrm{S}$ ) were positively correlated with hydraulic traits, such as $\mathrm{VD}_{\text {minor }}$ and $K_{\text {leaf }}$ (Fig. 7), these results are in agreement with previous studies $[11,26]$. Lower VD and $\mathrm{K}_{\text {leaf }}$ would make cell loss of turgor, shape and size and thus induce a decline of the photosynthetic surface area during leaf dehydration. This reduction of assimilation capacity that in turn limits the construction of vein, which indicates there is a tradeoff between the investment and return of leaf structure. Thus, it is due mainly to the common anatomical structures between non-xylem water transport pathways and $\mathrm{CO}_{2}$ diffusion pathways in the mesophyll cell [12]. In addition, these two main mesophyll traits were negatively related to PT/ST, suggesting that a trade-off between leaf anatomicaland economic traits. Relationships of paired traits displayed in Fig. 8 highlight that these anatomical traits play an essential role in coordinating a balance between water supply and $\mathrm{CO}_{2}$ uptake acclimation to drought. As the twice drought and re-watering cycles could improve plant tolerance to drought, so more attention should be paid to drought priming effects on leaf hydraulic and mesophyll anatomical changes to longterm drought in future.

\section{Conclusions}

In summary, the results of this study suggested that the decline in $g_{s}$ and $T_{r}$ under the long-term drought condition was mostly responsible for the reduction in stomatal aperture on the adaxial surface primarily due to reduced $K_{\text {leaf }}$, major vein width and minor vein density. Drought decreased $\mathrm{T}_{\text {mes }}$ and $\mathrm{S}_{\mathrm{c}} / \mathrm{S}$, however, increased $\mathrm{T}_{\mathrm{cw}}$ and $\mathrm{PT} /$ ST. Considering $g_{m}$, the decline of $T_{m e s}$ and $S_{c} / S$ were the crucial causes for $g_{m}$ decrement under drought. Furthermore, these anatomical traits related to hydraulic and economic traits were coordinated in three main tomato cultivars under controlled environment. The present study highlights the important role of leaf anatomy in maintaining the balance between water supply and $\mathrm{CO}_{2}$ diffusion in response to drought. 


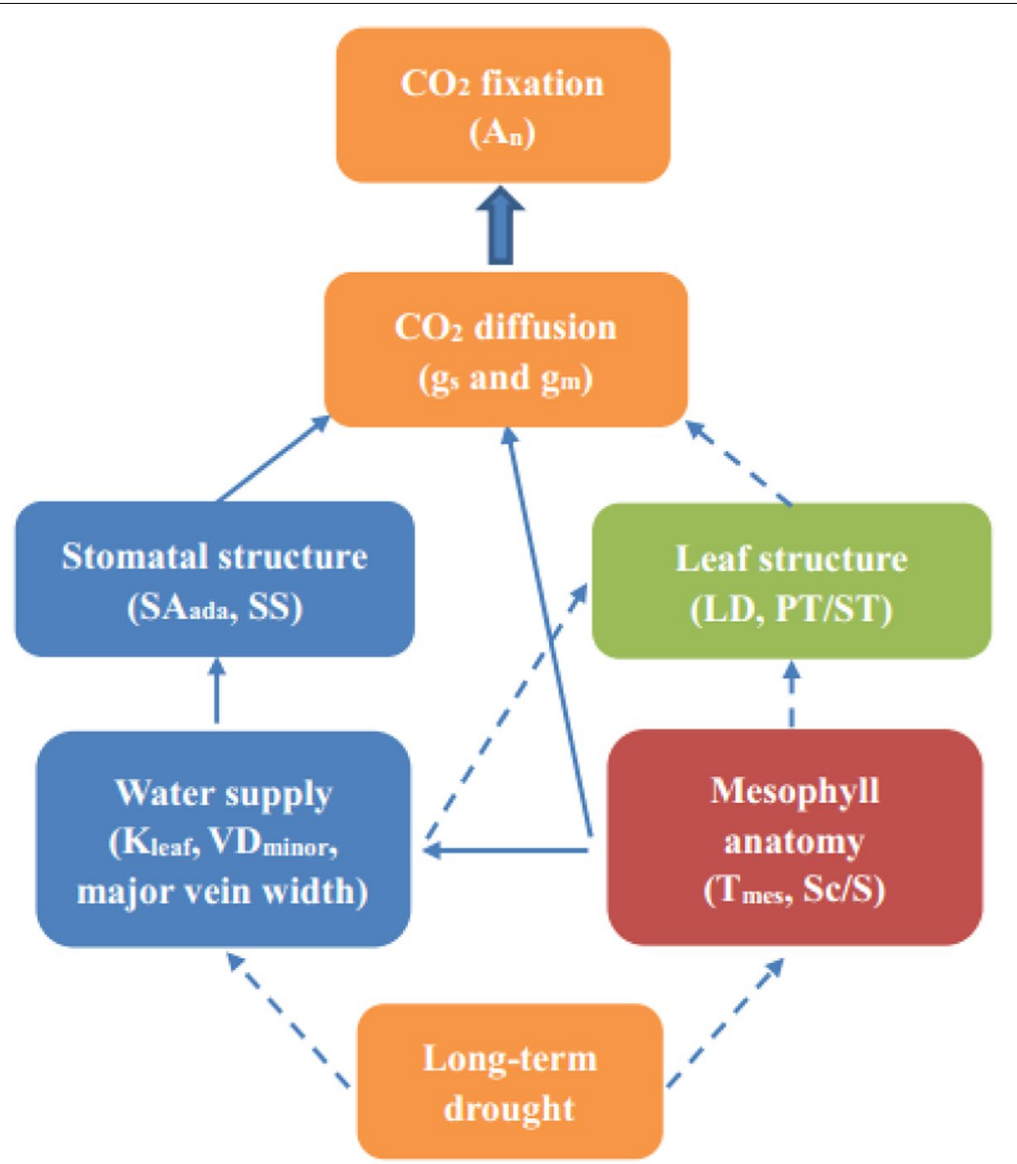

Fig. 8 The mechanistic links and coordination between the paired traits in response to long-term drought in this study. Red-shaded variables are related to mesophyll anatomical traits, blue-shaded variables are related to hydraulic trait, green-shaded variables are related to economics trait. Solid arrows indicate positive correlations; dotted arrows indicate negative correlations. All abbreviations are already defined in the text

\section{Materials and methods}

\section{Experimental design}

The experimental plants were Solanum lycopersicum L., cv. Helan108, purchased from Jinan Xuechao Seed Co. Ltd, Jinan city in China. The tomato seeds were sown in nursery seedling plate with nursery substrate (sphagnum peat, Pindstrup Mosebrug A/S, Ryomgaard, Denmark). The collection of seeds and the experimental researches on plant were complied with the national guidelines of China. When the second genuine leaf emerged, tomato seedlings were transplanted into $5.3 \mathrm{~L}$ pots (height $30 \mathrm{~cm}$, diameter $15 \mathrm{~cm}$ ) containing $6.5 \mathrm{~kg}$ air-dried sandy loam soil. The gravimetric field water capacity $\left(\theta_{\mathrm{FC}}\right)$ and wilting point were $22 \%\left(\mathrm{~g} \mathrm{~g}^{-1}\right)$ and $6.8 \%\left(\mathrm{~g} \mathrm{~g}^{-1}\right)$, respectively. To avoid any nutrient deficiency, $1 \mathrm{~g} \mathrm{~N}, 0.5 \mathrm{~g} \mathrm{P}$ and $0.9 \mathrm{~g} \mathrm{~K}$ were applied into each pot. After transplanting, all pots were irrigated to $85 \% \theta_{\mathrm{FC}}$. Seedlings were cultivated in an environment-controlled chamber with $12 \mathrm{~h}$ photoperiod at $600 \mu \mathrm{mol} \mathrm{m}{ }^{-2} \mathrm{~s}^{-1}$ photosynthetic photon flux density (PPFD). The day/night air temperature was $27-30{ }^{\circ} \mathrm{C} / 17-19^{\circ} \mathrm{C}$, relative humidity was kept $50-60 \%$. On the 14 th day after transplanting (DAT) with tomato seedlings displaying 3-4 true leaves, water treatments including, well-watered and progressive drought-stressed treatments, were conducted. For the well-watered treatment, soil moisture was maintained around $85 \% \theta_{\mathrm{FC}}$ during the entire growth period. For the progressive drought-stressed treatment, tomato plants were subjected to progressive soil drying and irrigated to $85 \% \theta_{\mathrm{FC}}$ when soil moisture decreased to $35 \% \theta_{\mathrm{FC}}$ aiming to maintain plant survival and growth. At the End of the third drying cycle on the 40th DAT, seedlings have expanded to 8-11 leaves in the flowering stage, all measurements, including gas exchange, hydraulic, economics and anatomical traits were performed on the same new, fully expanded leaves. 


\section{Leaf gas exchange and chlorophyll fluorescence measurements}

Leaf gas exchange and chlorophyll fluorescence were measured simultaneously using the Li-Cor 6400 Photosynthesis system (Li-Cor Inc., Lincoln, NE, USA) equipped with an integrated leaf fluorometer chamber head (Li-Cor 6400-40) from 9:00 am to 2:00 pm. During the measurements, PPFD was kept at $1500 \mu \mathrm{mol} \mathrm{m}{ }^{-2} \mathrm{~s}^{-1}$, the sample $\mathrm{CO}_{2}$ concentration was maintained at 400 $\mu \mathrm{mol} \mathrm{mol}{ }^{-1}$ using a $\mathrm{CO}_{2}$ cylinder. Due to drought has an effect on leaf temperature [60], so the leaf temperature was not controlled during the measurements. Leaf gas exchange and chlorophyll fluorescence were recorded when net photosynthesis $\left(A_{n}\right)$ was stabilized under these conditions. For each treatment, 6 plants were included.

The actual photochemical efficiency of photosystem II $\left(\Phi_{\text {PSII }}\right)$ was determined by measuring steady-state fluorescence $\left(\mathrm{F}_{\mathrm{s}}\right)$ and maximum fluorescence $\left(\mathrm{F}_{\mathrm{m}}^{\prime}\right)$ during a light-saturating pulse of ca. $8000 \mathrm{mmol} \mathrm{m}^{-2} \mathrm{~s}^{-1}$ :

$$
\Phi_{P S I I}=F_{m}^{\prime}-F_{s} / F_{m}^{\prime}
$$

The electron transport rate $\left(\mathrm{J}_{\mathrm{f}}\right)$ was then calculated as:

$$
J_{f}=\Phi_{P S I I} \times P P F D \times \alpha \times \beta
$$

where PPFD was maintained at $1500 \mu \mathrm{mol} \mathrm{m} \mathrm{m}^{-2} \mathrm{~s}^{-1}$ on both the well-watered and water-stressed leaves. $\alpha$ represents the leaf absorptance and $\beta$ reflects the partitioning of absorbed quanta between photosystems I and II.

To estimate $\alpha \times \beta$, light response curves were measured in these two treatments. PPFD was adjusted in a series of 200, 150, 100, 50, 20 and $0 \mu \mathrm{mol} \mathrm{m} \mathrm{m}^{-2} \mathrm{~s}^{-1}$ at $2 \%$ $\mathrm{O}_{2}$ by injecting a $\mathrm{N}_{2}$ cylinder. During each step of light change, the minimum and the maximum waiting times were 2 and $5 \mathrm{~min}$, respectively. The value of $\alpha \times \beta$ was determined from the linear slope of the relationship between total photosynthesis rate and $\left(\mathrm{PPFD} \times \Phi_{\mathrm{PSII}} / 4\right)$ derived from each light point [61].

The variable J method [62] was used to calculate $g_{m}$, as follows:

$$
g_{m}=\frac{A_{n}}{C_{i}-\frac{\Gamma^{*}\left(J_{f}+8\left(A+R_{d}\right)\right)}{J_{f}-4\left(A+R_{d}\right)}}
$$

where $\mathrm{C}_{\mathrm{i}}$ represents intercellular $\mathrm{CO}_{2}$ concentration $\left(\mu \mathrm{mol} \mathrm{CO}_{2} \mathrm{~mol}^{-1}\right), \mathrm{R}_{\mathrm{d}}$ represents the light mitochondrial respiration $\left(\mu \mathrm{mol} \mathrm{CO}_{2} \mathrm{~m}^{-2} \mathrm{~s}^{-1}\right)$ and was calculated as $1 / 2$ of the dark respiration $\left(R_{n}\right)[33,63], R_{n}$ was measured in the dark environment after the light was turned off for $3 \mathrm{~h}$. $\Gamma^{*}$ is the chloroplast $\mathrm{CO}_{2}$ compensation point in the absence of respiration $\left(\mu \mathrm{mol} \mathrm{CO}_{2}\right.$ $\mathrm{mol}^{-1}$ ) and calculated according to [64] .

\section{Measurements of leaf hydraulic traits}

Leaf hydraulic conductance $\left(\mathrm{K}_{\text {leaf }}\right)$ was calculated from the transpiration rate $\left(\mathrm{T}_{\mathrm{r}}\right)$ and the water potential gradient between water potential of distilled water $\left(\Psi_{\text {water }}\right)$ and leaf water potential ( $\left.\Psi_{\text {leaf }}\right)[26], \Psi_{\text {leaf }}$ was measured by a WP4C Dew point Potential Meter (Decagon, Pullman, WA, USA).

$$
K_{\text {leaf }}=\frac{T_{r}}{\Psi_{\text {water }}-\Psi_{\text {leaf }}}
$$

In this study, major veins referred to veins that extend from the petiole. According to [53], major vein density $\left(\mathrm{VD}_{\text {major }}\right)$ was calculated as the total length of the major veins per leaf area. To measure minor vein density $\left(\mathrm{VD}_{\text {minor }}\right), 1 \mathrm{~cm}^{2}$ pieces were cut from the center of each leaf (avoiding major veins) and placed in $10 \%$ $\mathrm{NaOH}$ solution. Samples were placed in a 90-degree water bath for $40 \mathrm{~min}$. Each sample was washed in distilled water and then stained in $1 \%$ safranin for 30-60 s. The samples were then put onto glass slides and photographed under a light microscope Teelen XSP 360 A (Teelen Inc., Shanghai, China) at $\times 4$ magnifications. $V D_{\text {minor }}\left(\mathrm{mm} \mathrm{mm}^{-2}\right)$ was calculated as the total length of leaf veins per leaf area using Image J software (National Institutes of Health, Bethesda, MD, USA). A piece near to $2 \mathrm{~cm}$ from the petiole (including the major veins) was also cut to measure the major vein width. For each treatment, three replications were selected and $\mathrm{VD}_{\text {minor }}$ was averaged with two different fields of views. Leaf adaxial and abaxial epidermis were removed using forceps and then placed in absolute ethyl alcohol for $10 \mathrm{~min}$, samples were mounted upside down on a glass slide. Stomatal anatomical traits including stomatal aperture and length were observed at $\times 400$ magnification in three randomly selected of views, stomatal density (SD) was observed under a light microscope at $\times 100$ magnification. SD was calculated as the total numbers of stomata per area using Image J software. Anatomical maximum stomatal conductance to water vapor $\left(\mathrm{g}_{\text {smax }}, \mathrm{mol} \mathrm{H}_{2} \mathrm{O} \mathrm{m}^{-2} \mathrm{~s}^{-1}\right)$ were then calculated according to [51] as follows:

$$
g_{\text {smax }}=\frac{d \times S D \times \alpha_{\max }}{v\left(L+\frac{\pi}{2} \sqrt{\frac{\alpha_{\max }}{\pi}}\right)}
$$

where $\mathrm{d}$ is the diffusivity of water in air $\left(24.6 \times 10^{-6}\right.$ $\mathrm{m}^{2} \mathrm{~s}^{-1}$ at $\left.25{ }^{\circ} \mathrm{C}\right), v$ is the molar volume of the air $\left(24.4 \times 10^{-3} \mathrm{~m}^{3} \mathrm{~mol}^{-1}\right.$ at $25^{\circ} \mathrm{C}$ and $\left.101.3 \mathrm{kPa}\right), \mathrm{L}$ is the stomatal pore depth, which was approximated as (stomatal length/2) and $\alpha_{\max }$ is the maximum area of the open stomatal pore $\left(\mathrm{m}^{2}\right)$, which was calculated as $\pi \times$ (stomatal length/4) ${ }^{2}$. 


\section{Measurements of leaf morphological traits}

Leaf area was measured using the LI-3000 C Area Meter (Li-Cor Inc., Lincoln, NE USA). Leaf thickness (LT, mm) was measured as an average of the total thickness of leaves using digital Vernier calipers (SATA Tools Co., Ltd, Shanghai, China), avoiding the influence of leaf major veins. Leaf samples were then oven-dried to a constant weight at $75^{\circ} \mathrm{C}$ and their biomass was recorded. Leaf dry mass per area (LMA, $\mathrm{g} \mathrm{m}^{-2}$ ) was calculated dry mass per leaf area. Leaf tissue density ( $\mathrm{LD}, \mathrm{g} \mathrm{cm}^{-3}$ ) was calculated as the ratio of LMA to LT. For each treatment, six replications were made.

\section{Measurements of leaf anatomic traits}

Following gas exchange measurements, leaf segments (1 $\mathrm{mm}^{2}$ ) were cut from the central leaflet regions, avoiding the veins, and then fixed with $2.5 \%$ glutaraldehyde $(\mathrm{v} / \mathrm{v})$ in $0.1 \mathrm{M}$ phosphate buffer for $4 \mathrm{~h}$ and washed three times using $0.1 \mathrm{M}$ phosphate buffer $(\mathrm{pH}=7)$ for $15 \mathrm{~min}$. The leaf material was fixed in $1 \%$ osmium tetroxide for $2 \mathrm{~h}$ at $4{ }^{\circ} \mathrm{C}$. Then, the samples were dehydrated with a graded ethanol series (50, 70, 80, 90, $95 \%$ and $100 \%)$ embedded in Spurr's resin. Paraffin $(6 \mu \mathrm{m})$ for light microscopy and ultrathin $(50 \mathrm{~nm})$ for transmission electron microscopy (TEM) sections were cut with a Leica RM2016 ultra microtome (Leica Microsystems, Wetzlar, Germany). The light microscope sections were stained with safranin $\mathrm{O}$ and fast green and viewed with magnifications of $\times 100$ and $\times 200$ under a light microscope with a Nikon DS-U3 digital camera (Nikon Incorporation, Tokyo, Japan) to measure palisade thickness, spongy thickness, mesophyll thickness, the total cross-sectional area of mesophyll cells $\left(\Sigma \mathrm{S}_{\mathrm{s}}\right)$ and the total length of mesophyll cell exposed to the intercellular air space $\left(\mathrm{L}_{\mathrm{mes}}\right)$. The ultrathin cross-sections were imaged using a transmission electron microscope at magnifications of $\times 500-800$ to measure chloroplast distribution and $\times 10,000-15,000$ to measure cell wall thickness $\left(T_{c w}\right)$. Two leaves from different plants of each treatment were analyzed. The volume fraction of intercellular air spaces $\left(f_{\text {ias }}\right)$, surface area of mesophyll exposed to intercellular air spaces per leaf area $\left(\mathrm{S}_{\mathrm{m}} / \mathrm{S}\right)$, and chloroplast surface area exposed to intercellular air space per leaf area $\left(\mathrm{S}_{\mathrm{c}} / \mathrm{S}\right)$ were calculated according to [54]:

$$
\begin{aligned}
& f_{\text {ias }}=1-\frac{\text { o }}{\text { a } S_{s}} \\
& T_{\text {mes }} W \\
& S_{\text {mes }} / S=\frac{L_{\text {mes }}}{W} F \\
& S_{c} / S=\frac{L_{c}}{L_{\text {mes }}} S_{\text {mes }} / S
\end{aligned}
$$

where $\mathrm{W}$ is the width of the measured section $(\mu \mathrm{m})$, $\mathrm{T}_{\text {mes }}$ is the mesophyll thickness between two epidermises $(\mu \mathrm{m}), \mathrm{L}_{\mathrm{c}}$ is the length of chloroplasts exposed to the intercellular air space $(\mu \mathrm{m})$, and $\mathrm{F}$ is the curvature correction factor being 1.42 according to [54].

\section{Statistical analysis}

Statistical analyses were performed using SPSS 16.0 (IBM SPSS Statistics, Chicago, IL, USA). Normality and equal variances were tested before analysis of variance. The significance of differences between CK and the droughtstressed treatment were analyzed using the one-way analysis of variance (ANOVA) according to Duncan's multiple range tests at $P<0.05$ or $P<0.01$. Pearson correlation coefficients $(r)$ were calculated to examine the relationships between key traits. Further, multivariate associations of leaf traits were analyzed using principal component analysis (PCA) in CANOCO 5 (Microcomputer Power, Ithaca, NY, USA). Redundancy analysis (RDA) was used to assess the relationships among leaf water loss, stomatal structure and water supply as well as among carbon fixation, leaf economic and anatomic traits in CANOCO 5. All graphics were performed in Origin-Pro 2017 (Origin Lab, Northampton, MA, USA).

\section{Abbreviations}

$\mathrm{T}_{\mathrm{r}}$ : transpiration rate; $\mathrm{g}_{\mathrm{s}}$ : stomatal conductance; SD: stomatal density; SS: stomatal size; SA: stomatal aperture; aba: leaf abaxial side; ada: leaf adaxial side; $\mathrm{K}_{\text {leaf: }}$ leaf hydraulic conductance; $V D_{\text {major: }}$ : major vein density; $V D_{\text {minor: }}$ minor vein density; $\Psi_{\text {water }}$ : water potential of distilled water; $\psi_{\text {leaf }}$ : leaf water potential; $g_{\text {wmax }}$ : the calculated maximum stomatal conductance to water vapor; PPFD: photosynthetic photon flux density; DAT: days after transplanting; $A_{n}$ : net photosynthetic rate; $A_{\max }$ : leaf maximum photosynthetic capacity; $a$ : leaf absorptance; $\beta$ : the partitioning of absorbed quanta between photosystems I and II (PSI and PSII); $J_{f}$ : electron transport rate; $d$ : the diffusivity of water in air; $v$ : the molar volume of air; $L$ : the stomatal pore depth; $a_{\max }$ : the maximum area of the open stomatal pore; $\Phi_{\text {PSII }}$ : actual photochemical efficiency of photosystem II; $F_{s}$ : steady-state fluorescence; $F_{m}^{\prime}$ : maximum fluorescence; $S_{m} / S$ : surface area of mesophyll exposed to intercellular air spaces per leaf area; $\Sigma S_{s}$ : the tota cross-sectional area of mesophyll cells; $L_{\text {mes }}$ : the total length of mesophyll cell exposed to the intercellular air space; $W$ : the width of the measured section; $T_{\text {mes }}$ : the mesophyll thickness between two epidermises; $L_{c}$ : the length of chloroplasts exposed to the intercellular air space; F: the curvature correction factor; LMA: leaf dry mass per area; LT: leaf thickness; LD: leaf density; PT/ST: ratio between palisade and spongy mesophyll thickness; $g_{m}$ : mesophyll conductance to $\mathrm{CO}_{2} ; \mathrm{T}_{\mathrm{cw}}$ : cell wall thickness; $\mathrm{f}_{\text {ias }}$ : the volume fraction of intercellular air spaces; $S_{c} / S_{\text {: the }}$ chlorophyll surface area exposed to leaf intercellular air spaces per leaf area; VPD: vapor pressure difference; CK: well-watered.

\section{Supplementary Information}

The online version contains supplementary material available at https://doi. org/10.1186/s12870-021-03304-y.

Additional file 1.

Acknowledgements

We are grateful to our colleagues in the laboratory for the assistance of the experiment, and to the anonymous reviewers for valuable comments. 


\section{Supportinginformation}

Additional supporting information may be found online in the Supporting Information section at the end of the article.

\section{Authors' contributions}

Yang Gao and Aiwang Duan conceived and designed the study. Shuang Li, Abdoul Kader Mounkaila Hamani, and Yingying Zhang performed sample preparations, and laboratory and data analyses. Shuang Li, Abdoul Kader Mounkaila Hamani wrote the manuscript and Yingying Zhang, Yueping Liang, Yang Gao and Aiwang Duan revised the manuscript. The author(s) read and approved the final manuscript.

\section{Funding}

This study was financially supported by the National Natural Science Foundation of China (Grant No. 51879267, 51779259), the Agricultural Science and Technology Innovation Program (ASTIP), Chinese Academy of Agricultural Sciences, Science and Technology Project of Henan Province (212102110278).

\section{Availability of data and materials}

The data that support the findings of this study are available from the corresponding author upon reasonable request.

\section{Declarations}

\section{Ethics approval and consent to participate}

Not applicable.

\section{Consent for publication}

Not applicable.

\section{Competing interests}

The authors declare that they have no competing interests.

\section{Author details}

${ }^{1}$ Farmland Irrigation Research Institute, Key Laboratory of Crop Water Use and Regulation, Chinese Academy of Agriculture Sciences, Ministry of Agriculture and Rural Affairs, Xinxiang, Henan 453002, China. ${ }^{2}$ Graduate School of Chinese Academy of Agricultural Sciences, Beijing 100081, China.

Received: 11 July 2021 Accepted: 29 October 2021

Published online: 15 November 2021

\section{References}

1. Oikonomou PD, Karavitis CA, Tsesmelis DE, Kolokytha E, Maia R: Drought Characteristics Assessment in Europe over the Past 50 Years. Water Resources Management 2020, 34(15):4757-4772.

2. Trenberth KE, Dai A, van der Schrier G, Jones PD, Barichivich J, Briffa KR, Sheffield J: Global warming and changes in drought. Nature Climate Change 2013, 4(1):17-22.

3. Sack L, Scoffoni C: Leaf venation: structure, function, development, evolution, ecology and applications in the past, present and future. New Phytol 2013, 198(4):983-1000.

4. Xiong D, Flexas J: Leaf economics spectrum in rice: leaf anatomical, biochemical, and physiological trait trade-offs. J Exp Bot 2018, 69(22):5599-5609.

5. Zhou H, Zhou G, He Q, Zhou L, Ji Y, Zhou M: Environmental explanation of maize specific leaf area under varying water stress regimes. Environ Exp Bot 2020, 171:103932.

6. Yin Q, Wang L, Lei M, Dang H, Quan J, Tian T, Chai Y, Yue M: The relationships between leaf economics and hydraulic traits of woody plants depend on water availability. Sci Total Environ 2018, 621:245-252.

7. Sack L, Scoffoni C, John GP, Poorter H, Mason CM, Mendez-Alonzo $R$, Donovan LA: How do leaf veins influence the worldwide leaf economic spectrum? Review and synthesis. J Exp Bot 2013, 64(13):4053-4080.

8. Blonder B, Violle C, Bentley LP, Enquist BJ: Venation networks and the origin of the leaf economics spectrum. Ecol Lett 2011, 14(2):91-100.
9. Zhu X, Cao Q, Sun L, Yang X, Yang W, Zhang H: Stomatal Conductance and Morphology of Arbuscular Mycorrhizal Wheat Plants Response to Elevated CO2 and NaCl Stress. Front Plant Sci 2018, 9:1363.

10. Wright IJ, Reich PB, Westoby M, Ackerly DD, Baruch Z, Bongers F, Cavender-Bares J, Chapin T, Cornelissen JHC, Diemer M et al: The worldwide leaf economics spectrum. Nature 2004, 428(6985):821-827.

11. Flexas J, Scoffoni C, Gago J, Sack L: Leaf mesophyll conductance and leaf hydraulic conductance: an introduction to their measurement and coordination. J Exp Bot 2013, 64(13):3965-3981.

12. Xiong D, Nadal M: Linking water relations and hydraulics with photosynthesis. Plant J 2020, 101(4):800-815.

13. Hetherington AM, Woodward Fl: The role of stomata in sensing and driving environmental change. Nature 2003, 424(6951):901-908.

14. Yin Q, Tian T, Kou M, Liu P, Wang L, Hao Z, Yue M: The relationships between photosynthesis and stomatal traits on the Loess Plateau. Global Ecology and Conservation 2020, 23:e01146.

15. Du Q, Xing G, Jiao X, Song X, Li J: Stomatal responses to long-term high vapor pressure deficits mediated most limitation of photosynthesis in tomatoes. Acta Physiologiae Plantarum 2018, 40(8).

16. Xu Z, Zhou G: Responses of leaf stomatal density to water status and its relationship with photosynthesis in a grass. J Exp Bot 2008, 59(12):3317-3325.

17. Raven JA: Speedy small stomata? J Exp Bot 2014, 65(6):1415-1424.

18. Niinemets U: Global-scale climatic controls of leaf dry mass per area, density, and thickness in trees and shrubs. Ecology 2001, 82(2):453-469

19. Xiong D, Wang D, Liu X, Peng S, Huang J, Li Y: Leaf density explains variation in leaf mass per area in rice between cultivars and nitrogen treatments. Ann Bot 2016, 117(6):963-971.

20. Zhu S-D, Song J-J, Li R-H, Ye Q: Plant hydraulics and photosynthesis of 34 woody species from different successional stages of subtropical forests. Plant Cell Environ 2013, 36(4):879-891

21. Li L, McCormack ML, Ma C, Kong D, Zhang Q, Chen X, Zeng H, Niinemets U, Guo D: Leaf economics and hydraulic traits are decoupled in five species-rich tropical-subtropical forests. Ecol Lett 2015, 18(9):899-906.

22. Jin Y, Wang C, Zhou Z, Li Z: Co-ordinated performance of leaf hydraulics and economics in 10 Chinese temperate tree species. Funct Plant Biol 2016, 43(11):1082-1090.

23. Abbasi UA, You W-H, Yan E-R: Correlations between leaf economics, hydraulic, and shade-tolerance traits among co-occurring individual trees. Acta Oecologica 2021, 110:103673.

24. Han J, Lei Z, Zhang Y, Yi X, Zhang W, Zhang Y: Drought-introduced variability of mesophyll conductance in Gossypium and its relationship with leaf anatomy. Physiol Plant 2019, 166(3):873-887.

25. Tosens T, Niinemets U, Westoby M, Wright IJ: Anatomical basis of variation in mesophyll resistance in eastern Australian sclerophylls: news of a long and winding path. J Exp Bot 2012, 63(14):5105-5119.

26. Xiong D, Flexas J, Yu T, Peng S, Huang J: Leaf anatomy mediates coordination of leaf hydraulic conductance and mesophyll conductance to $\mathrm{CO} 2$ in Oryza. New Phytol 2017, 213(2):572-583.

27. Hassiotou F, Renton M, Ludwig M, Evans JR, Veneklaas EJ: Photosynthesis at an extreme end of the leaf trait spectrum: how does it relate to high leaf dry mass per area and associated structural parameters? Journal of Experimental Botany 2010, 61(11):3015-3028.

28. Tomas M, Flexas J, Copolovici L, Galmes J, Hallik L, Medrano H, RibasCarbo $M$, Tosens T, Vislap $V$, Niinemets $U$ : Importance of leaf anatomy in determining mesophyll diffusion conductance to $\mathrm{CO} 2$ across species: quantitative limitations and scaling up by models. J Exp Bot 2013, 64(8):2269-2281.

29. Muir CD, Hangarter RP, Moyle LC, Davis PA: Morphological and anatomical determinants of mesophyll conductance in wild relatives of tomato (Solanum sect. Lycopersicon, sect. Lycopersicoides; Solanaceae). Plant Cell Environ 2014, 37(6):1415-1426.

30. Tosens T, Niinemets U, Vislap V, Eichelmann H, Castro Diez P: Developmental changes in mesophyll diffusion conductance and photosynthetic capacity under different light and water availabilities in Populus tremula: how structure constrains function. Plant Cell Environ 2012, 35(5):839-856.

31. Lu Z, Lu J, Pan Y, Lu P, Li X, Cong R, Ren T: Anatomical variation of mesophyll conductance under potassium deficiency has a vital role in determining leaf photosynthesis. Plant Cell Environ 2016, 39(11):2428-2439.

32. Du Q, Liu T, Jiao X, Song X, Zhang J, Li J: Leaf anatomical adaptations have central roles in photosynthetic acclimation to humidity. J Exp Bot 2019, 70(18):4949-4962. 
33. Xiong D, Douthe C, Flexas J: Differential coordination of stomatal conductance, mesophyll conductance, and leaf hydraulic conductance in response to changing light across species. Plant Cell Environ 2018, 41(2):436-450.

34. Li H, Liu H, Gong X, Li S, Pang J, Chen Z, Sun J: Optimizing irrigation and nitrogen management strategy to trade off yield, crop water productivity, nitrogen use efficiency and fruit quality of greenhouse grown tomato. Agricultural Water Management 2021, 245:106570.

35. Liu H, Li H, Ning H, Zhang X, Li S, Pang J, Wang G, Sun J: Optimizing irrigation frequency and amount to balance yield, fruit quality and water use efficiency of greenhouse tomato. Agricultural Water Management 2019, 226:105787.

36. Wang X, Vignjevic M, Liu F, Jacobsen S, Jiang D, Wollenweber B: Drought priming at vegetative growth stages improves tolerance to drought and heat stresses occurring during grain filling in spring wheat. Plant Growth Regulation 2014, 75(3):677-687.

37. Flexas J, Diaz-Espejo A, Conesa MA, Coopman RE, Douthe C, Gago J, Galle A, Galmes J, Medrano H, Ribas-Carbo M et al: Mesophyll conductance to $\mathrm{CO} 2$ and Rubisco as targets for improving intrinsic water use efficiency in C3 plants. Plant Cell Environ 2016, 39(5):965-982.

38. Wang X, Du T, Huang J, Peng S, Xiong D: Leaf hydraulic vulnerability triggers the decline in stomatal and mesophyll conductance during drought in rice. J Exp Bot 2018, 69(16):4033-4045.

39. Drake PL, Froend RH, Franks PJ: Smaller, faster stomata: scaling of stomatal size, rate of response, and stomatal conductance. J Exp Bot 2013, 64(2):495-505.

40. Du Q, Jiao X, Song X, Zhang J, Bai P, Ding J, Li J: The Response of Water Dynamics to Long-Term High Vapor Pressure Deficit Is Mediated by Anatomical Adaptations in Plants. Front Plant Sci 2020, 11:758.

41. Caringella MA, Bongers FJ, Sack L: Leaf hydraulic conductance varies with vein anatomy across Arabidopsis thaliana wild-type and leaf vein mutants. Plant Cell Environ 2015, 38(12):2735-2746.

42. Lu Z, Xie K, Pan Y, Ren T, Lu J, Wang M, Shen Q, Guo S: Potassium mediates coordination of leaf photosynthesis and hydraulic conductance by modifications of leaf anatomy. Plant Cell Environ 2019, 42(7):2231-2244.

43. Brodribb TJ, Skelton RP, McAdam SA, Bienaime D, Lucani CJ, Marmottant $P$ : Visual quantification of embolism reveals leaf vulnerability to hydraulic failure. New Phytol 2016, 209(4):1403-1409.

44. Brodribb TJ, Holbrook NM: Stomatal Closure during Leaf Dehydration, Correlation with Other Leaf Physiological Traits. Plant Physiol 2003, 132(4):2166-2173.

45. Pantin F, Monnet F, Jannaud D, Costa JM, Renaud J, Muller B, Simonneau T, Genty B: The dual effect of abscisic acid on stomata. New Phytol 2013, 197(1):65-72.

46. Lamarque LJ, Delzon S, Toups H, Gravel Al, Corso D, Badel E, Burlett R, Charrier G, Cochard H, Jansen S et al: Over-accumulation of abscisic acid in transgenic tomato plants increases the risk of hydraulic failure. Plant Cell Environ 2020, 43(3):548-562.

47. Brodribb TJ, Jordan GJ: Water supply and demand remain balanced during leaf acclimation of Nothofagus cunninghamii trees. New Phytologist 2011, 192(2):437-448

48. Brodribb TJ, Feild TS, Sack L: Viewing leaf structure and evolution from a hydraulic perspective. Funct Plant Biol 2010, 37(6):488.

49. Buckley TN, John GP, Scoffoni C, Sack L: How Does Leaf Anatomy Influence Water Transport outside the Xylem? Plant Physiol 2015, 168(4):1616-1635.
50. Liu C, Li Y, Xu L, Chen Z, He N: Variation in leaf morphological, stomatal, and anatomical traits and their relationships in temperate and subtropical forests. Sci Rep 2019, 9(1):5803.

51. Franks PJ, Beerling DJ: Maximum leaf conductance driven by $\mathrm{CO}_{2}$ effects on stomatal size and density over geologic time. Proceedings of the National Academy of Sciences 2009, 106(25):10343-10347.

52. Drake PL, de Boer HJ, Schymanski SJ, Veneklaas EJ: Two sides to every leaf: water and $\mathrm{CO} 2$ transport in hypostomatous and amphistomatous leaves. New Phytol 2019, 222(3):1179-1187.

53. Lei ZY, Han JM, Yi XP, Zhang WF, Zhang YL: Coordinated variation between veins and stomata in cotton and its relationship with water-use efficiency under drought stress. Photosynthetica 2018, 56(4):1326-1335.

54. Evans JR, Caemmerer SV, Setchell BA, Hudson GS: The Relationship Between CO2 Transfer Conductance and Leaf Anatomy in Transgenic Tobacco With a Reduced Content of Rubisco. Funct Plant Biol 1994, 21(4):475.

55. Han J-M, Meng H-F, Wang S-Y, Jiang C-D, Liu F, Zhang W-F, Zhang Y-L: Variability of mesophyll conductance and its relationship with water use efficiency in cotton leaves under drought pretreatment. J Plant Physiol 2016, 194:61-71.

56. Tholen D, Boom C, Zhu XG: Opinion: prospects for improving photosynthesis by altering leaf anatomy. Plant Sci 2012, 197:92-101.

57. Terashima I, Hanba YT, Tholen D, Niinemets Ü: Leaf Functional Anatomy in Relation to Photosynthesis. Plant Physiol 2010, 155(1):108-116.

58. Jiao X-C, Song X-M, Zhang D-L, Du Q-J, Li J-M: Coordination between vapor pressure deficit and $\mathrm{CO} 2$ on the regulation of photosynthesis and productivity in greenhouse tomato production. Sci Rep 2019, 9(1):8700.

59. Shirke PA, Pathre UV: Influence of leaf-to-air vapour pressure deficit (VPD) on the biochemistry and physiology of photosynthesis in Prosopis juliflora*. Journal of Experimental Botany 2004, 55(405):2111-2120.

60. Zandalinas SI, Mittler R, Balfagon D, Arbona V, Gomez-Cadenas A: Plant adaptations to the combination of drought and high temperatures. Physiol Plant 2018, 162(1):2-12.

61. Valentini R, EPRON D, DE ANGELIS P, MATTEUCCI G, DREYER E: In situ estimation of net $\mathrm{CO} 2$ assimilation, photosynthetic electron flow and photorespiration in Turkey oak (Q. cerris L.) leaves: diurnal cycles under different levels of water supply. Plant Cell Environ 1995, 18(6):631-640.

62. Harley PC, Loreto F, Marco GD, Sharkey TD: Theoretical Considerations when Estimating the Mesophyll Conductance to CO2 Flux by Analysis of the Response of Photosynthesis to CO2. Plant Physiol 1992, 98(4):1429-1436.

63. Niinemets Ü, CESCATTI A, RODEGHIERO M, TOSENS T: Leaf internal diffusion conductance limits photosynthesis more strongly in older leaves of Mediterranean evergreen broad-leaved species. Plant Cell Environ 2005, 28(12):1552-1566.

64. Sharkey TD, Bernacchi CJ, Farquhar GD, Singsaas EL: Fitting photosynthetic carbon dioxide response curves for C3leaves. Plant Cell Environ 2007, 30(9):1035-1040.

\section{Publisher's Note}

Springer Nature remains neutral with regard to jurisdictional claims in published maps and institutional affiliations.

Ready to submit your research? Choose BMC and benefit from:

- fast, convenient online submission

- thorough peer review by experienced researchers in your field

- rapid publication on acceptance

- support for research data, including large and complex data types

- gold Open Access which fosters wider collaboration and increased citations

- maximum visibility for your research: over $100 \mathrm{M}$ website views per year

At BMC, research is always in progress.

Learn more biomedcentral.com/submissions 